\title{
Material Selection for Accident Tolerant Fuel Cladding
}

\author{
B.A. PINT, K.A. TERRANI, Y. YAMAMOTO, and L.L. SNEAD
}

\begin{abstract}
Alternative cladding materials to $\mathrm{Zr}$-based alloys are being investigated for accident tolerance, which can be defined as $>100 \mathrm{X}$ improvement (compared to $\mathrm{Zr}$-based alloys) in oxidation resistance to steam or steam- $\mathrm{H}_{2}$ environments at $\geq 1473 \mathrm{~K}\left(1200{ }^{\circ} \mathrm{C}\right)$ for short times. After reviewing a wide range of candidates, current steam oxidation testing is being conducted on Mo, MAX phases, and $\mathrm{FeCrAl}$ alloys. Recently reported low-mass losses for Mo in steam at $1073 \mathrm{~K}$ $\left(800{ }^{\circ} \mathrm{C}\right.$ ) could not be reproduced. Both $\mathrm{FeCrAl}$ and $\mathrm{MAX}$ phase $\mathrm{Ti}_{2} \mathrm{AlC}$ form a protective alumina scale in steam. However, commercial $\mathrm{Ti}_{2} \mathrm{AlC}$ that was not single phase, formed a much thicker oxide at $1473 \mathrm{~K}\left(1200{ }^{\circ} \mathrm{C}\right)$ in steam and significant $\mathrm{TiO}_{2}$, and therefore, $\mathrm{Ti}_{2} \mathrm{AlC}$ may be challenging to form as a cladding or a coating. Alloy development for $\mathrm{FeCrAl}$ is seeking to maintain its steam oxidation resistance to $1748 \mathrm{~K}\left(1475^{\circ} \mathrm{C}\right)$, while reducing its $\mathrm{Cr}$ content to minimize susceptibility to irradiation-assisted $\alpha^{\prime}$ formation. The composition effects and critical limits to retaining protective scale formation at $>1673 \mathrm{~K}\left(1400{ }^{\circ} \mathrm{C}\right)$ are still being evaluated.
\end{abstract}

DOI: $10.1007 / \mathrm{s} 40553-015-0056-7$

(C) ASM International (ASM) and The Minerals, Metals \& Materials Society (TMS) 2015

\section{INTRODUCTION}

SINCE the nuclear accident in Japan in 2011, ${ }^{[1,2]}$ considerable research has been devoted to identify light water reactor (LWR) fuel systems that tolerate severe accident scenarios (i.e., beyond design basis accidents). ${ }^{[3-9]}$ The objective is to provide larger safety margins, i.e., delay the onset of severe LWR core degradation by reducing the rate of $\mathrm{H}_{2}$ and heat generated by the rapid oxidation of $\mathrm{Zr}$-base alloy cladding and increase the coping time after an accident. ${ }^{[7-9]}$ Thus, one of the key criteria for new fuel cladding is to identify materials with oxidation rates $\geq 100 \mathrm{X}$ slower than $\mathrm{Zr}$-base alloys. ${ }^{[7]}$

Various $\mathrm{Fe}-\mathrm{Cr}, \mathrm{Fe}-\mathrm{Cr}-\mathrm{Ni}$, and $\mathrm{Fe}-\mathrm{Cr}-\mathrm{Al}$ alloys have been evaluated for this application as well as $\mathrm{SiC}$ and

B.A. PINT, Group Leader and Distinguished Research and Development Staff, and Y. YAMAMOTO, Research and Development Staff, are with the Materials Science and Technology Division, Oak Ridge National Laboratory, Oak Ridge TN 37831-6156. Contact e-mail: pintba@ornl.gov K.A. TERRANI, Research and Development Staff and ORNL FCRD Program Manager, is with the Fusion \& Materials for Nuclear Systems Division, Oak Ridge National Laboratory. L.L. SNEAD, formerly a Corporate Fellow and FCRD Program Manager, is with the Materials Science and Technology Division, Oak Ridge National Laboratory.

This manuscript has been authored by UT-Battelle, LLC under Contract No. DE-AC05-00OR22725 with the U.S. Department of Energy. The United States Government retains and the publisher, by accepting the article for publication, acknowledges that the United States Government retains a non-exclusive, paid-up, irrevocable, world-wide license to publish, or reproduce the published form of this manuscript, or allow others to do so, for United States Government purposes. The Department of Energy will provide public access to these results of federally sponsored research in accordance with the DOE Public Access Plan (http://energy.gov/downloads/doe-publicaccess-plan).

Manuscript submitted July 31, 2014.

Article published online September 14, 2015
Mo. Recently, the latter was reported to have better steam oxidation resistance than previously reported. ${ }^{[10]}$ Alumina-forming materials represent an attractive option, including FeCrAl-type alloys and MAX phase compositions, such as $\mathrm{Ti}_{2} \mathrm{AlC} .^{[11,12]}$ This study reports the ranking of the reaction kinetics of the various classes of alloys and the current status of steam oxidation behavior of $\mathrm{Mo}, \mathrm{Ti}_{3} \mathrm{SiC}_{2}, \mathrm{Ti}_{2} \mathrm{AlC}$, and $\mathrm{FeCrAl}$ alloys, the latter being a promising candidate where the focus is on alloy development to improve its tensile properties while retaining steam oxidation resistance to $1748 \mathrm{~K}$ $\left(1475^{\circ} \mathrm{C}\right)$. Previously, the effect of steam pressure (up to 20.7 bar) and $\mathrm{H}_{2}$ additions was investigated and found to have limited effect on the oxidation behavior of the most oxidation-resistant alloys. ${ }^{[3,4]}$ Therefore, the steam oxidation results reported in this study were conducted at 1 bar.

\section{EXPERIMENTAL PROCEDURE}

Specimens evaluated in this study were coupons typically $\sim 1.5-\mathrm{mm}$ thick and 4 to $5 \mathrm{~cm}^{2}$ in surface area with compositions given in Table I in mass pct. Unfortunately there was not sufficient MAX phase material to obtain chemical compositions of those specimens by the same inductively coupled plasma \& combustion analytical techniques. Commercial alloys evaluated included $\mathrm{La}_{2} \mathrm{O}_{3}$-dispersed Mo (Rhenium Alloys Moly LX) and three MAX phases: commercial $\mathrm{Ti}_{3} \mathrm{SiC}_{2}$ and $\mathrm{Ti}_{2} \mathrm{AlC}$ and high-purity laboratory-produced $\mathrm{Ti}_{2} \mathrm{AlC}$. The model FeCrAl alloys were typically cast at ORNL followed by hot rolling and annealing at $973 \mathrm{~K}\left(700{ }^{\circ} \mathrm{C}\right)$. The Fe13Cr5AlY alloy was extruded at $1323 \mathrm{~K}\left(1050{ }^{\circ} \mathrm{C}\right)$ followed by a 1 hour annealing at $973 \mathrm{~K}\left(700{ }^{\circ} \mathrm{C}\right)$. The 2nd generation $\mathrm{FeCrAl}$ alloys were hot-rolled (C135) or 
hot-extruded $(\mathrm{C} 135 \mathrm{Nb})$ at $1073 \mathrm{~K}\left(800^{\circ} \mathrm{C}\right)$ followed by annealing at $1073 \mathrm{~K}\left(800{ }^{\circ} \mathrm{C}\right)$ for 1 hour. Oxidation experiments were conducted in three different systems: (1) thermal gravimetric analysis (TGA) in 1 bar of Ar-50 pet $\mathrm{H}_{2} \mathrm{O}$ or dry air at $1473 \mathrm{~K}\left(1200{ }^{\circ} \mathrm{C}\right)$, using a Cahn model 1000 microbalance with a quartz tube, (2) magnetic suspension TGA using a Rubotherm DynTHERM LP-HT-II instrument where the alumina test chamber was fully isolated with dry air or 100 pct steam at $1073 \mathrm{~K}$ to $1773 \mathrm{~K}\left(800{ }^{\circ} \mathrm{C}\right.$ to $\left.1500{ }^{\circ} \mathrm{C}\right)$, and (3) a high-temperature [maximum $1973 \mathrm{~K}\left(1700{ }^{\circ} \mathrm{C}\right)$ ] test rig consisting of a vertical alumina tube with two resistively heated furnaces where steam or air entered the bottom of the tube and was preheated to $1273 \mathrm{~K}$ to $1573 \mathrm{~K}$ $\left(1000{ }^{\circ} \mathrm{C}\right.$ to $\left.1300{ }^{\circ} \mathrm{C}\right)$ by the first furnace and the specimen was held in the second furnace in an alumina holder attached to the top tube using an alumina pin. ${ }^{[13]}$ For the TGA experiments, the specimen was suspended with a Pt-Rh wire, which experienced little evaporation in steam or Ar-50 pct $\mathrm{H}_{2} \mathrm{O}$. The deionized water used to generate steam was not Ar-bubbled or filtered as is typically done for $\sim 873 \mathrm{~K}\left(600{ }^{\circ} \mathrm{C}\right)$ steam testing, thus the $\mathrm{O}_{2}$ content was $\sim 10 \mathrm{ppm}$. At $1473 \mathrm{~K}\left(1200{ }^{\circ} \mathrm{C}\right)$, the equilibrium $\mathrm{O}_{2}$ partial pressure in 1 bar steam was calculated as $\sim 125 \mathrm{ppm} \mathrm{O}$. However, at $1073 \mathrm{~K}$ $\left(800{ }^{\circ} \mathrm{C}\right)$, the equilibrium $\mathrm{O}_{2}$ level is $<1 \mathrm{ppm}$. The gas velocity in the TGA experiments was typically 1 to $2 \mathrm{~cm} / \mathrm{s}$ while the steam velocity was 5 to $60 \mathrm{~cm} / \mathrm{s}$ in the high-temperature furnace. The mass change of all specimens was measured using a Mettler Toledo model XP205 balance with $\pm 0.04 \mathrm{mg}$ or $\pm 0.01 \mathrm{mg} / \mathrm{cm}^{2}$ accuracy. After exposure, specimens were metallographically sectioned and examined by light microscopy. More extensive characterization of the reaction products has been provided elsewhere ${ }^{[4,14]}$ or will be provided in future publications. Tensile properties were measured at $573 \mathrm{~K}\left(300{ }^{\circ} \mathrm{C}\right)$ in laboratory air using SS-3 sub-sized sheet specimens $(25-\mathrm{mm}$ long, gage of $0.8 \times 5 \mathrm{~mm})$ with a strain rate of $10^{-3} / \mathrm{s}$.

\section{RESULTS AND DISCUSSION}

Figure 1 provides an overview of the steam oxidation kinetic data of the various fuel cladding candidates. ${ }^{[4,13,15-17]}$ The data were fitted to an Arrhenius relationship

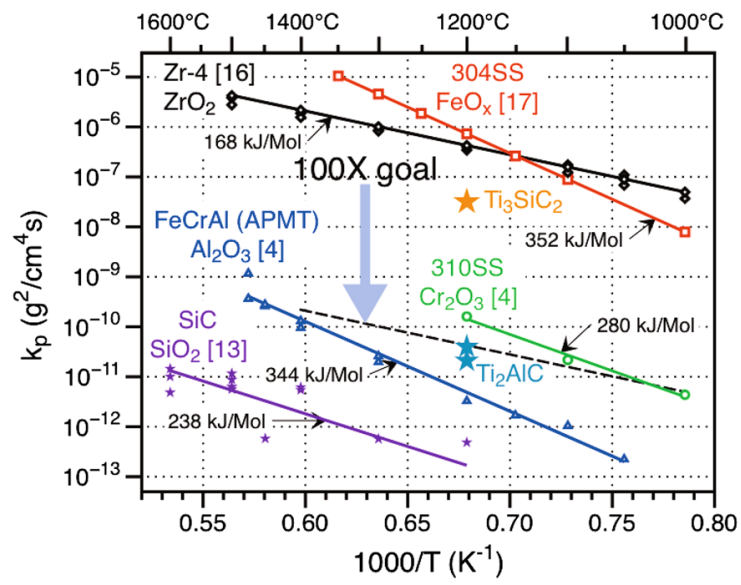

Fig. 1-Arrhenius plot of the steam oxidation rate constants for various candidate materials ${ }^{[4,13,15-17]}$ with the resulting oxidation activation energies noted. Current results for MAX phase materials are also shown.

Table I. Alloy Compositions (Mass Pet and ppmw) Determined by Inductively Coupled Plasma \& Combustion Techniques

\begin{tabular}{|c|c|c|c|c|c|c|c|c|c|c|c|c|}
\hline Alloy & $\mathrm{Fe}$ & $\mathrm{Zr}$ & $\mathrm{Ni}$ & $\mathrm{Cr}$ & $\mathrm{Al}$ & Mo & $\mathrm{Mn}$ & $\mathrm{Si}$ & $\mathrm{C}$ & $\mathrm{O}$ & $\mathrm{S}$ & Other \\
\hline Zircaloy-2 & 0.1 & 98.1 & 0.1 & 0.1 & & & & 0.01 & 0.019 & 0.115 & $<$ & $1.4 \mathrm{Sn}$ \\
\hline Zircaloy-4 & 0.22 & 98.2 & - & 0.11 & - & - & - & 0.01 & 0.016 & 0.118 & $<$ & $1.27 \mathrm{Sn}$ \\
\hline $304 \mathrm{~L}$ & & 70.3 & - & 8.27 & 18.8 & 0.01 & 0.27 & 0.73 & 0.42 & 0.028 & 0.006 & $<$ \\
\hline $310 \mathrm{SS}$ & 51.9 & $<$ & 19.5 & 25.4 & & 0.13 & 1.89 & 0.70 & 0.044 & 0.006 & 10 & $0.15 \mathrm{Co}, 0.1 \mathrm{Cu}$ \\
\hline E-Brite & 72.6 & 0.1 & 25.8 & & & 1.0 & $<$ & 0.2 & 0.003 & 0.003 & 100 & $0.1 \mathrm{~V}, 0.1 \mathrm{Nb}$ \\
\hline Fe15Cr5AlY & 79.9 & $<$ & $<$ & 15.0 & 5.0 & $<$ & $<$ & 0.01 & 0.004 & 0.001 & 12 & $0.033 \mathrm{Y}$ \\
\hline Fe13Cr5AlY & 82.1 & $<$ & $<$ & 12.9 & 4.9 & $<$ & $<$ & 0.01 & 0.004 & 0.002 & 13 & $0.031 \mathrm{Y}$ \\
\hline Fe13Cr5AlY-2 & 82.3 & $<$ & $<$ & 13.2 & 4.4 & $<$ & $<$ & 0.01 & 0.002 & 0.001 & 3 & $0.12 \mathrm{Y}$ \\
\hline C135 & 80.9 & $<$ & $<$ & 12.7 & 4.2 & 1.9 & $<$ & 0.20 & 0.003 & 0.002 & 7 & $0.031 \mathrm{Y}, 0.04 \mathrm{~W}$ \\
\hline $\mathrm{C} 135 \mathrm{C}$ & 81.0 & $<$ & $<$ & 12.5 & 4.2 & 1.9 & $<$ & 0.21 & 0.09 & 0.002 & 5 & $0.026 \mathrm{Y}$ \\
\hline $\mathrm{C} 135 \mathrm{Nb}$ & 78.2 & & & 13.3 & 5.2 & 2.1 & & 0.22 & $<0.01$ & $<50$ & $1 \mathrm{Nb}, 0.03 \mathrm{Y}$ & \\
\hline PM2000 & 74.6 & - & 0.1 & 18.9 & 5.1 & 0.01 & 0.11 & 0.04 & 0.01 & 0.25 & 8 & $0.37 \mathrm{Y}, 0.45 \mathrm{Ti}$ \\
\hline APMT & 69.8 & 0.11 & 0.18 & 21.2 & 4.8 & 2.8 & 0.10 & 0.47 & 0.036 & 0.053 & $<3$ & $0.21 \mathrm{Y}, 0.17 \mathrm{Hf}, 0.02 \mathrm{Ti}$ \\
\hline MA956 & 74.2 & $<$ & 0.08 & 20.0 & 4.5 & $<$ & 0.08 & 0.07 & 0.015 & 0.199 & 25 & $0.40 \mathrm{Y}, 0.37 \mathrm{Ti}$ \\
\hline APM & 73.3 & 0.10 & - & 20.4 & 5.5 & - & 0.08 & 0.23 & 0.030 & 0.053 & 10 & $0.03 \mathrm{Ti},<0.01 \mathrm{Y}$ \\
\hline SUH21 & 78.6 & $<$ & 0.11 & 17.7 & 3.0 & 0.01 & 0.12 & 0.29 & 0.008 & 0.003 & $<3$ & $0.11 \mathrm{Ti},<3 \mathrm{ppmY}$ \\
\hline Alkrothal 720 & 81.4 & 0.06 & 0.12 & 13.0 & 4.2 & $<$ & 0.44 & 0.30 & 0.034 & 15 & 0.002 & $0.44 \mathrm{Ti},<3 \mathrm{ppmY}$ \\
\hline Alkrothal 14 & 80.3 & 0.12 & 0.11 & 14.7 & 4.2 & $<$ & 0.20 & 0.17 & 0.029 & $<$ & 14 & $0.01 \mathrm{Ti},<3 \mathrm{ppmY}$ \\
\hline Alkrothal 3 & 82.7 & 0.09 & $<$ & 13.4 & 3.3 & $<$ & 0.20 & 0.22 & 0.027 & $<$ & 12 & $0.02 \mathrm{Ti},<3 \mathrm{ppmY}$ \\
\hline Ohmaloy30 & 82.8 & $<$ & 0.58 & 12.6 & 2.6 & 0.05 & 0.41 & 0.26 & 0.017 & $<$ & $<3$ & $0.34 \mathrm{Ti}, 0.1 \mathrm{~V}$ \\
\hline Ohmaloy40 & 81.7 & $<$ & 0.53 & 12.7 & 3.6 & 0.10 & 0.37 & 0.22 & 0.021 & $<$ & $<3$ & $0.34 \mathrm{Ti}, 0.13 \mathrm{~V}$ \\
\hline Mo LX & 0.02 & $<$ & $<$ & 0.01 & $<$ & 99.3 & $<$ & 0.01 & 0.001 & 0.098 & $<3$ & $0.56 \mathrm{La}$ \\
\hline CVD-SiC & - & - & 0.01 & - & - & - & 一 & 69.8 & 30.2 & 0.003 & $<$ & - \\
\hline
\end{tabular}

$<$ denotes below the detectable limit of 0.01 or 0.001 pct for interstitials. 


$$
k_{\mathrm{p}}=k_{\mathrm{o}} \exp \left(-E_{\mathrm{a}} / R T\right),
$$

where $k_{\mathrm{p}}$ is the thermogravimetric parabolic rate constant (with units of $\mathrm{g}^{2} / \mathrm{cm}^{4} \mathrm{~s}$ ), $k_{\mathrm{o}}$ is a constant, $E_{\mathrm{a}}$ is the activation energy, $R$ is the gas constant, and $T$ is temperature in Kelvin. The values fitted from the referenced data sets are shown in Table II. From Figure 1 it is clear that the reaction rates for $\mathrm{Zr}$-based cladding and conventional $18 \mathrm{Cr}-8 \mathrm{Ni}$ stainless steel, such as type $304 \mathrm{~L}$, are similar because the stainless steel cannot form a protective scale in steam at these temperatures and instead rapidly oxidizes to form $\mathrm{FeO}_{\mathrm{x}}$. Thus, these $18 \mathrm{Cr}-8 \mathrm{Ni}$ austenitic steels (e.g., types 304, 321, and 347) that were previously used as LWR cladding ${ }^{[18]}$ do not meet the accident tolerance criteria as they rapidly form $\mathrm{FeO}_{\mathrm{x}}$ at $<1473 \mathrm{~K}\left(1200{ }^{\circ} \mathrm{C}\right)$ in steam. $^{[3,4]}$

In order to achieve a 100X improvement in oxidation resistance for $\mathrm{Zr}$-based alloys, i.e., $1 \mu \mathrm{m}$ of oxide formed rather than $100 \mu \mathrm{m}$, the parabolic rate constant, $k_{\mathrm{p}}$, would need to decrease by a factor of $10^{4}$, as shown by the dashed line in Figure 1. Higher alloyed (Ni and/or $\mathrm{Cr}$ ) stainless steels, such as type 310 (310SS) shown in Figure 1, provide close to the desired $100 \mathrm{X}$ reduction due to the formation of a protective $\mathrm{Cr}_{2} \mathrm{O}_{3}$ scale in steam. ${ }^{[4]}$ However, these compositions are not desirable for this application because of the high neutronic penalty of $\mathrm{Ni}^{[7]}$ The steam oxidation resistance of ferritic (12 to 25 pct $\mathrm{Cr},<1$ pct $\mathrm{Ni}$ ) steels also was investigated but $\geq 22$ pct $\mathrm{Cr}$ was required even with $\mathrm{Mn}$, $\mathrm{Si}$, and $\mathrm{Y}$ additions. ${ }^{[15]}$ This level of $\mathrm{Cr}$ is a concern due to the potential embrittlement from $\alpha^{\prime}$ formation during irradiation. ${ }^{[7,19,20]}$ Thus, $\mathrm{Cr}_{2} \mathrm{O}_{3}$-forming alloys have been evaluated and are potential secondary candidates for this application.

From Figure 1 it is clear that both alumina and silica scales have lower reaction rates and can remain protective to much higher temperatures. The silica scale formed on $\mathrm{SiC}$ has excellent steam oxidation resistance up to at least $1973 \mathrm{~K}\left(1700^{\circ} \mathrm{C}\right)^{[13]}$ but many other aspects of its utilization as nuclear fuel cladding, including thermo-mechanical reliability ${ }^{[21]}$ and hydrothermal corrosion resistance, have not yet been proven sufficient. ${ }^{[22]}$

Figure 2 illustrates the rates shown in Figure 1 at $1373 \mathrm{~K}$ and $1473 \mathrm{~K}\left(1100{ }^{\circ} \mathrm{C}\right.$ and $\left.1200{ }^{\circ} \mathrm{C}\right)$ in 1 bar steam. After only $1 \mathrm{~h}$ at $1373 \mathrm{~K}\left(1100{ }^{\circ} \mathrm{C}\right)$, the $\mathrm{ZrO}_{2}$ scale was $>100 \mu \mathrm{m}$, Figure 2(a). At a higher magnification, Figure 2(b) shows the chromia scale formed on a commercial $\mathrm{Fe}-26 \mathrm{Cr}-1 \mathrm{Mo}$ alloy (E-Brite) after 4 hours at $1473 \mathrm{~K}\left(1200{ }^{\circ} \mathrm{C}\right)$. This alloy is shown instead of $310 \mathrm{SS}$, because the chromia scale spalled from $310 \mathrm{SS}$ on cooling due to its higher thermal expansion mismatch between the alloy and the chromia scale. ${ }^{[23]}$ Figure 2(c) shows the slower growing $\alpha-\mathrm{Al}_{2} \mathrm{O}_{3}$ scale formed on APMT (Fe-22Cr-5Al-3Mo) after a similar 4 hours exposure at $1473 \mathrm{~K}\left(1200{ }^{\circ} \mathrm{C}\right)$.

Based on the limitations of chromia-forming steels and silica-forming ceramics, alumina-forming claddings appear to be an attractive solution for further focus. Yet recently it was suggested that the steam oxidation rate of Mo was much lower than in air and this material should be further considered. ${ }^{[10]}$ These results were quite surprising and appeared to contradict decades old understanding of Mo oxidation. ${ }^{[24-26]}$ In order to

Table II. Steam Oxidation Rate Data for Materials Representing Various Classes of Candidates

\begin{tabular}{|c|c|c|c|c|c|}
\hline Material & Temp. Range $\left[\mathrm{K}\left({ }^{\circ} \mathrm{C}\right)\right]$ & $k_{\mathrm{o}}\left(\mathrm{g} / \mathrm{cm}^{2} \mathrm{~s}^{1 / 2}\right)$ & $E_{\mathrm{a}}(\mathrm{kJ} / \mathrm{mol})$ & Scale & References \\
\hline Zirc-4 & 1273 to $1773(1000$ to 1500$)$ & $3.64 \times 10^{-1}$ & 168 & $\mathrm{ZrO}_{2}$ (tetragonal) & [16] \\
\hline $304 \mathrm{SS}$ & 1273 to $1623(1000$ to 1350$)$ & $2.40 \times 10^{6}$ & 352 & $\mathrm{FeO}_{\mathrm{x}}$ & {$[17]$} \\
\hline $310 \mathrm{SS}$ & 1273 to 1473 (1000 to 1200$)$ & 1.17 & 280 & $\mathrm{Cr}_{2} \mathrm{O}_{3}$ & [4] \\
\hline APMT & 1323 to 1748 (1050 to 1475$)$ & 7.84 & 344 & $\mathrm{Al}_{2} \mathrm{O}_{3}$ (corundum) & {$[4,15]$} \\
\hline $\mathrm{SiC}$ & 1473 to 1873 (1200 to 1600$)$ & $3.81 \times 10^{-5}$ & 238 & $\mathrm{SiO}_{2}$ (cristobalite)* & {$[13]$} \\
\hline
\end{tabular}

* In $\mathrm{H}_{2} \mathrm{O}$ environments, $\mathrm{SiO}_{2}$ forms $\mathrm{Si}(\mathrm{OH})_{4}$.
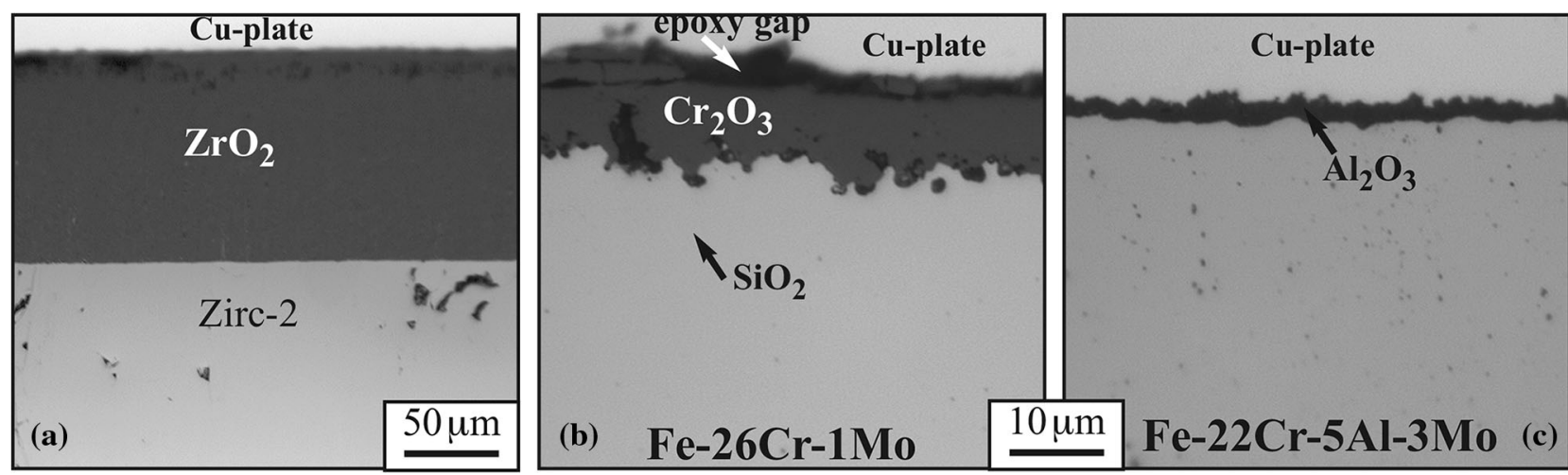

Fig. 2-Light microscopy of polished cross sections of specimens exposed to 1 bar steam (a) Zircaloy-2 tube after $1 \mathrm{~h}$ at $1373 \mathrm{~K}\left(1100{ }^{\circ} \mathrm{C}\right)$, (b) Fe-26Cr-1Mo coupon after $4 \mathrm{~h}$ at $1473 \mathrm{~K}\left(1200{ }^{\circ} \mathrm{C}\right)$, and $(c)$ FeCrAlMo coupon after $4 \mathrm{~h}$ at $1473 \mathrm{~K}\left(1200{ }^{\circ} \mathrm{C}\right)$. 
confirm these newer results, $\mathrm{La}_{2} \mathrm{O}_{3}$-doped Mo specimens were oxidized in steam and in air at $1073 \mathrm{~K}\left(800^{\circ} \mathrm{C}\right)$ for 4 hours in the high-temperature test module. (This rig could be more easily cleaned after testing than the TGA rigs by replacing the alumina reaction tube, which became contaminated with $\mathrm{MoO}_{3}$.) Thus, only final mass change was generated, rather than continuous mass gain curves reported in the prior study. ${ }^{[10]}$ Figure 3(a) compares the results from this study after 4 hours at $1073 \mathrm{~K}\left(800{ }^{\circ} \mathrm{C}\right)$ in dry air and steam and values extrapolated to $4 \mathrm{~h}$ from Reference 10 at $1073 \mathrm{~K}$ $\left(800{ }^{\circ} \mathrm{C}\right)$. In both environments, the present results showed higher mass gains than the prior study. Both studies agreed that the mass loss was reduced in steam compared to dry air. However, the present results are $<3 \mathrm{X}$ reduction in steam compared to a $>100 \mathrm{X}$ reduction measured previously. There are a number of differences between the two studies including the $\mathrm{La}_{2} \mathrm{O}_{3}$-doped $\mathrm{Mo}$ used in this study, the lower $\mathrm{O}_{2}$ content in the steam in the prior study, and the difference in gas flow rates. Further work will be needed to study these issues and resolve the differences between the two data sets. As an example of the complexity encountered, the current results had a $5.8 \mathrm{~cm} / \mathrm{s}$ gas flow rate in both environments, while the prior results had a flow rate of $\sim 9 \mathrm{~cm} / \mathrm{s}$. Initial ORNL experiments to determine the effect of flow rate found an unusual result. Increasing the flow rate in steam to $12 \mathrm{~cm} / \mathrm{s}$ resulted in a reduced mass loss $\left(173 \mathrm{mg} / \mathrm{cm}^{2}\right)$ compared to $229 \mathrm{mg} /$ $\mathrm{cm}^{2}$ at $5.8 \mathrm{~cm} / \mathrm{s}$ at $1073 \mathrm{~K}\left(800{ }^{\circ} \mathrm{C}\right)$. Nominally it would be expected that increasing the flow rate would increase the evaporation of a volatile reaction product. However, the appearance of the former specimen suggests that the greater surface oxide retained on the surface may have inhibited mass loss, Figure 3(b). The competition between volatilization and oxide formation was noted earlier for this temperature range. ${ }^{[2]}$ The effect of velocity on steam oxidation requires further study.

MAX phase ceramics are another class of potential candidates with hundreds of potential compositions. ${ }^{[27,28]}$ The recent focus has been on $\mathrm{Ti}_{2} \mathrm{AlC}$, as an alumina-forming material that could be used as a bulk
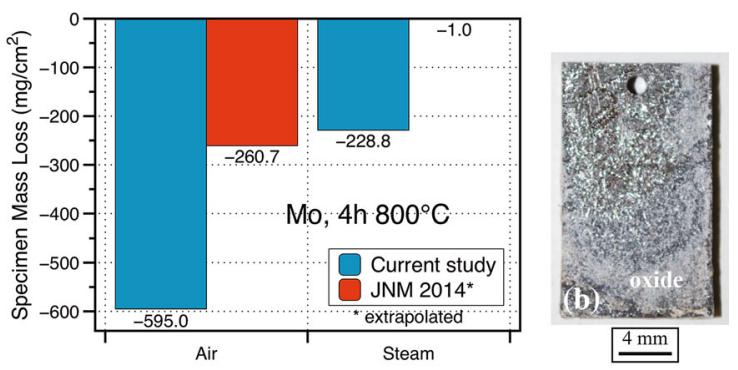

(a)

Fig. 3-(a) Comparison between the mass gain measured in this study with a $5.8 \mathrm{~cm} / \mathrm{s}$ gas flow rate and $\mathrm{La}_{2} \mathrm{O}_{3}$-doped Mo specimens exposed and extrapolated values from Ref. [10] in steam and dry air for $4 \mathrm{~h}$ at $1073 \mathrm{~K}\left(800{ }^{\circ} \mathrm{C}\right),(b)$ image of a $\mathrm{La}_{2} \mathrm{O}_{3}$-doped Mo specimen exposed in steam for $4 \mathrm{~h}$ at $1073 \mathrm{~K}\left(800^{\circ} \mathrm{C}\right)$ at $12 \mathrm{~cm} / \mathrm{s}$ flow rate where the mass loss was only $173 \mathrm{mg} / \mathrm{cm}^{2}$. material or a coating. ${ }^{[1,12,29]}$ In order to compare MAX phase performance to alumina-forming $\mathrm{FeCrAl}$ alloys, two commercial MAX phase materials were obtained, $\mathrm{Ti}_{3} \mathrm{SiC}_{2}$ and $\mathrm{Ti}_{2} \mathrm{AlC}$. Figure 4(a) shows the TGA results for these materials in steam at $1473 \mathrm{~K}\left(1200{ }^{\circ} \mathrm{C}\right)$. The $\mathrm{Ti}_{3} \mathrm{SiC}_{2}$ specimen formed a thick $\mathrm{TiO}_{2}$-rich scale that was identified by $x$-ray diffraction (XRD), rather than $\mathrm{SiO}_{2}$. In Figure 4(b), the thick oxide appears to have two layers but has not been further characterized because the high oxidation rate $\left(3 \times 10^{-8} \mathrm{~g}^{2} \mathrm{~cm}^{4} / \mathrm{s}\right)$ does not meet the criteria for this application, Figure 1. This reaction product appears very similar to the previous studies in air at $1473 \mathrm{~K}\left(1200{ }^{\circ} \mathrm{C}\right)$ where the outer layer was $\mathrm{TiO}_{2}$ and the inner layer a mixed $\mathrm{TiO}_{2}-\mathrm{SiO}_{2} \cdot{ }^{[30]}$

The commercial $\mathrm{Ti}_{2} \mathrm{AlC}$ specimen exhibited a much lower mass gain but the steady state rate constant was $4 \times 10^{-11} \mathrm{~g}^{2} \mathrm{~cm}^{4} / \mathrm{s}$, about $10 \mathrm{X}$ higher than expected for an alumina-forming alloy at this temperature, Figure 1. After exposure, the $\mathrm{Ti}_{3} \mathrm{SiC}_{2}$ specimen was gold, while the $\mathrm{Ti}_{2} \mathrm{AlC}$ specimen had some fraction of gold in the gray scale. Characterization of the scale and substrate by XRD determined that the scale was 16 vol pct $\mathrm{TiO}_{2}$ and the substrate was 3.5 pct TiC. In cross section, the scale was not uniformly thin, Figure 4(c), further suggesting that this commercial grade material could not form a uniform alumina scale under these conditions. A high-purity $\mathrm{Ti}_{2} \mathrm{AlC}$ ( 0 pct $\mathrm{TiC}$ detected by XRD) specimen was exposed under the same conditions and showed a much lower mass gain, Figure 4(a). The cross section shown in Figure 4(d) is much more uniform but still 5 pct $\mathrm{TiO}_{2}$ was detected in the scale and the rate constant was $2 \times 10^{-11} \mathrm{~g}^{2} \mathrm{~cm}^{4} / \mathrm{s}$, which is higher than the rate observed for FeCrAl, Figure 1. The presence of $\mathrm{TiO}_{2}$ in the scale formed in air on $\mathrm{Ti}_{2} \mathrm{AlC}$ has been previously reported. ${ }^{[29]}$ Thus, even with the best processing, $\mathrm{Ti}_{2} \mathrm{AlC}$ is difficult to fabricate commercially with the precise composition necessary to form alumina in steam at $1473 \mathrm{~K}\left(1200{ }^{\circ} \mathrm{C}\right)$, and likely will be difficult to fabricate as a thin oxidation-resistant coating on a $\mathrm{Zr}$-based cladding. ${ }^{[31]}$ Additional characterization and steam oxidation testing of these specimens at higher

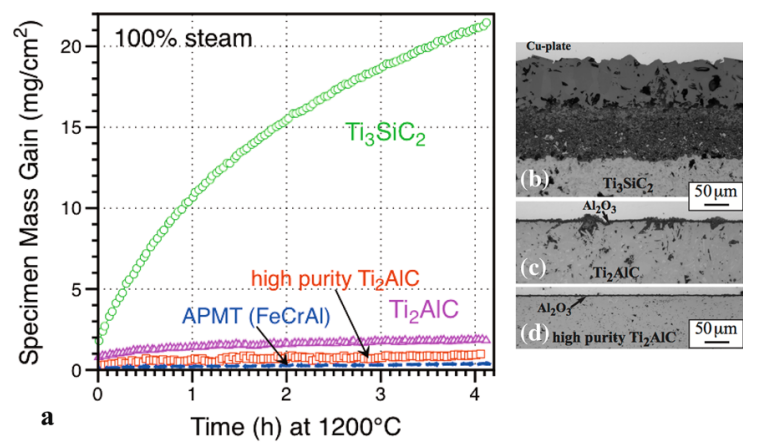

(a)

Fig. 4-(a) Mass gain as a function of exposure time to $1473 \mathrm{~K}$ $\left(1200^{\circ} \mathrm{C}\right)$ steam for three different MAX phase specimens compared to APMT (FeCrAl) and light microscopy of polished cross sections of these specimens (b) $\mathrm{Ti}_{3} \mathrm{SiC}_{2},(c)$ commercial $\mathrm{Ti}_{2} \mathrm{AlC}$, and $(d)$ high-purity $\mathrm{Ti}_{2} \mathrm{AlC}$. 
temperatures is in progress and will be reported in more detail elsewhere.

The majority of the recent work has focused on optimizing FeCrAl, which appears to have many of the features desirable for an accident tolerant fuel cladding. Most of the initial testing ${ }^{[3,4,14,15]}$ was performed on conventional Fe-20Cr-5Al alloys such as APMT and PM2000, an oxide dispersion strengthened (ODS) FeCrAl that is no longer commercially available. Figure 5 shows that APMT can form a protective alumina scale even at $1748 \mathrm{~K}\left(1475^{\circ} \mathrm{C}\right)$ for 4 hours exposure in steam and also in dry air. However, 4 hours at $1773 \mathrm{~K}\left(1500{ }^{\circ} \mathrm{C}\right)$ (close to the solidus temperature) in steam fully consumed the APMT specimen. The mass gain results for APMT in steam were similar in both the Rubotherm TGA and the high-temperature test module, Figure 5.

For the fuel cladding application, recent neutron irradiation results at the High Flux Isotope Reactor at ORNL of model Fe-(10 to $18 \mathrm{pct}) \mathrm{Cr}-\mathrm{Al}$ alloys have confirmed the concern that high $>14$ pet $\mathrm{Cr}$ will result in a large number density of $\alpha^{\prime}$ precipitates leading to potential embrittlement problems. ${ }^{[32]}$ Thus, an alloy development effort has focused on identifying lower $\mathrm{Cr}$ FeCrAl compositions. Figure 6 is an evolving study of the effect of $\mathrm{Cr}$ and $\mathrm{Al}$ content on protective scale behavior at $1473 \mathrm{~K}\left(1200{ }^{\circ} \mathrm{C}\right)$ on both commercial and model $\mathrm{FeCrAl}$ alloys. Initially, evaluations were done in the Cahn TGA in Ar-50 pct $\mathrm{H}_{2} \mathrm{O}^{[15]}$ but more recent results were obtained in the Rubotherm TGA using 100 pet $\mathrm{H}_{2} \mathrm{O}$ that shifted some of the results. ${ }^{[14]}$ The open symbols in Figure 6 were protective, meaning they formed a slow-growing alumina scale for 4 hours in steam, while the shaded symbols formed Fe-rich oxide nodules in $\mathrm{Ar}-50$ pet $\mathrm{H}_{2} \mathrm{O}$ or 100 pet $\mathrm{H}_{2} \mathrm{O}$ and were not considered protective, as they behaved more like the 304SS in Figure 1. The model alloys suggest that $\sim 17.5$ pct $\mathrm{Cr}$ is needed with 3 to 4 pct $\mathrm{Al}$ contents to form a protective alumina scale at $1473 \mathrm{~K}\left(1200{ }^{\circ} \mathrm{C}\right)$ in

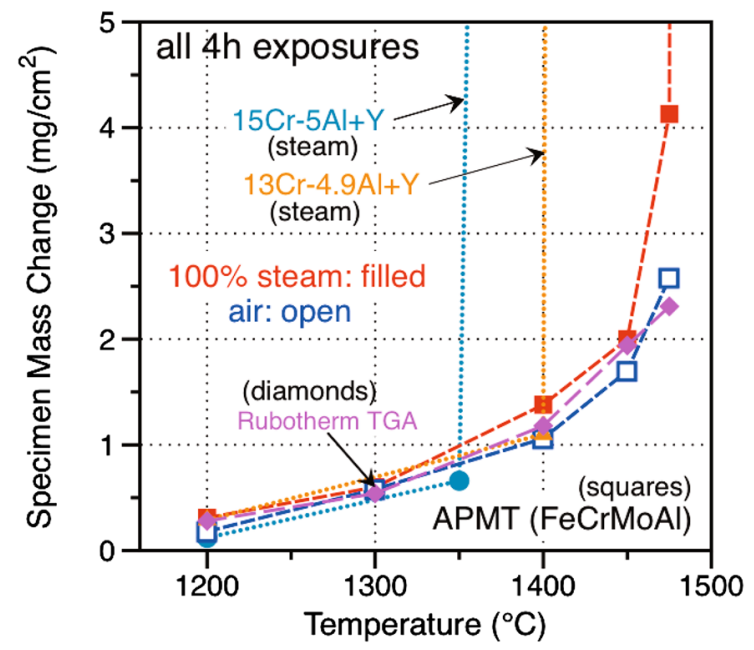

Fig. 5- Specimen mass change in $4 \mathrm{~h}$ exposures at each temperature in either 1 bar steam or flowing air (APMT only) for several FeCrAl alloys. Exposures were conducted in the high-temperature furnace except for the APMT data in steam from the Rubotherm TGA (diamonds) which indicated similar performance in the two systems. steam. However, at lower $\mathrm{Cr}$ contents that are less likely to form $\alpha^{\prime}$ during irradiation, it is clear that the Al content needs to be $\geq 5$ pct.

Returning to Figure 5, a surprising aspect of the alloy development was that these leaner compositions were not able to form alumina at $1748 \mathrm{~K}\left(1475^{\circ} \mathrm{C}\right)$ or even $1723 \mathrm{~K}$ $\left(1450{ }^{\circ} \mathrm{C}\right)$, like APMT. Figure 5 shows that a Fe-13Cr-5Al + Y alloy was limited to $1673 \mathrm{~K}\left(1400{ }^{\circ} \mathrm{C}\right)$ [i.e., not protective at $1698 \mathrm{~K}\left(1425^{\circ} \mathrm{C}\right)$ ] but a Fe-15Cr-5Al + Y alloy could not form alumina at $1673 \mathrm{~K}\left(1400{ }^{\circ} \mathrm{C}\right)$ but did form a protective alumina scale at $1623 \mathrm{~K}\left(1350^{\circ} \mathrm{C}\right)$. Nominally the capability should increase with increasing $\mathrm{Cr}$ content to the $\sim 21$ pct $\mathrm{Cr}$ level found in APMT. The beneficial effect of $\mathrm{Cr}$ on alumina scale formation is traditionally referred to as the "third" element effect but the $\mathrm{Cr}$ effect on the maximum use temperature has not previously been considered. ${ }^{[33]}$ The issue of maximum temperature capability is still being studied through a combination of isothermal steam exposures and "ramp" testing where the specimen is exposed in the Rubotherm TGA with the temperature increasing 5 degrees/min and steam introduced at $873 \mathrm{~K}$ $\left(600^{\circ} \mathrm{C}\right) .{ }^{[14]}$ When the specimen can no longer form a protective alumina scale, the large mass increase is detected by the TGA and the heating stopped.

Figure 7 shows an example of the current alloy development efforts to increase the $573 \mathrm{~K}\left(300{ }^{\circ} \mathrm{C}\right)$ tensile properties of a $13 \mathrm{Cr}-5 \mathrm{Al}$ alloy with the compositions shown in Table I. Note that a different Fe-13Cr-5Al + Y alloy was used for the oxidation testing shown in Figure 5. A larger heat with a slightly different composition was melted in order to measure the tensile properties and conduct initial tube fabrication trials. Additions of Mo and $\mathrm{Si}$ and variations with $\mathrm{C}$ and $\mathrm{Nb}$, among other elements have been investigated and processed by different methods, as noted in the previous section. These

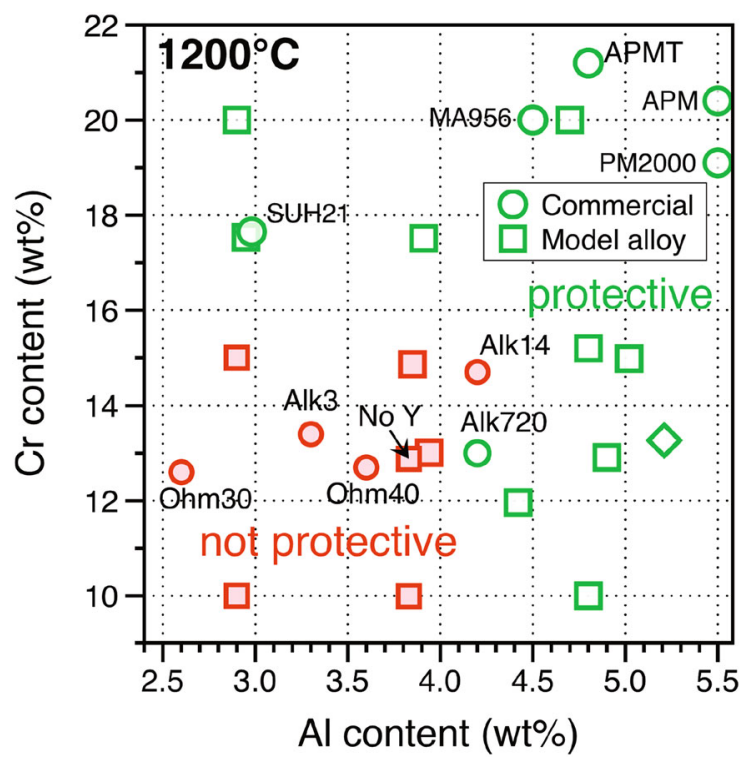

Fig. 6-Effect of $\mathrm{Cr}$ and $\mathrm{Al}$ alloy content on steam oxidation resistance at $1473 \mathrm{~K}\left(1200{ }^{\circ} \mathrm{C}\right)$ in commercial (circles) and model (squares) FeCrAl alloys, showing compositions which form a thin, protective alumina scale with open symbols and those that cannot form alumina in steam with shaded symbols. 


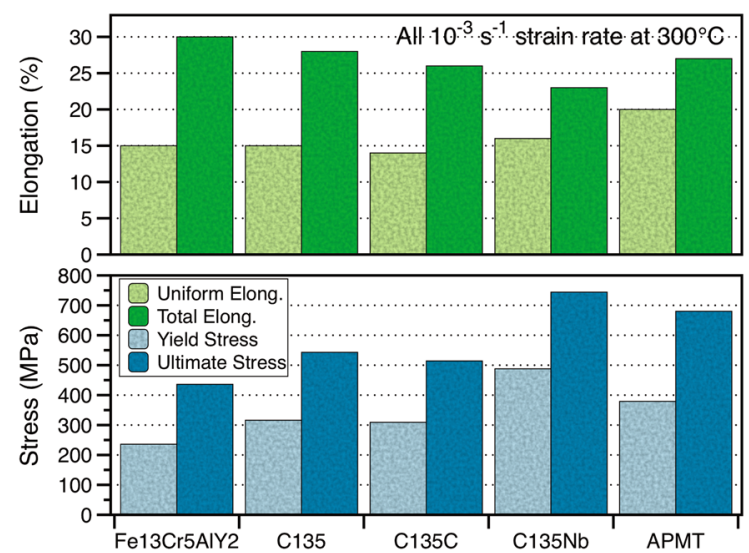

Fig. 7 -Tensile properties at $573 \mathrm{~K}\left(300^{\circ} \mathrm{C}\right)$ for several $\mathrm{FeCrAl}$ alloys with a $10^{-3} / \mathrm{s}$ strain rate.

composition and thermal mechanical strategies to obtain improved microstructures and secondary phases that pin grain boundaries (e.g., Laves phase with $\mathrm{Nb}$ in $\mathrm{C} 135 \mathrm{Nb}^{[34]}$ ) have successfully increased the yield strength by 30 to 100 pct compared to the initial Fe-13Cr-5Al composition, while maintaining ductility similar to the commercial APMT alloy, Figure 7. A higher strength alloy allows for a thinner cladding wall, which minimizes the neutronics penalty for $\mathrm{FeCrAl}$ compared to $\mathrm{Zr}$-based cladding. ${ }^{[7]}$ An alternative strategy being pursued is to develop a low-Cr ODS FeCrAl alloy for this application. ${ }^{[3,36]}$ In that case, the tensile properties are much higher but there is increased concern about the maximum operating temperature and the ability to fabricate thin tubing from an ODS alloy.

Maintaining the maximum temperature capability in these modified alloys remains a concern. One strategy has been to increase the $\mathrm{Al}$ content above 5 pct (e.g., alloy $\mathrm{C} 135 \mathrm{Nb}$ ) compared to only 4.2 pct in some of the initial modified heats, Table I. Steam oxidation testing of the new alloys is still in progress but Figure 8(c) shows a protective scale formed on one of the new higher strength alloys $(\mathrm{C} 135 \mathrm{C})$, with a scale similar in thickness to that formed on APMT (Figure 8(a)) and a cast version of Fe-15Cr-5Al-Y (Figure 8(b)). This cast alloy, nearly identical in composition to the alloy shown in Figure 5, did form a protective scale at $1673 \mathrm{~K}\left(1400{ }^{\circ} \mathrm{C}\right)$. However, the fine oxide precipitates observed in the alloy adjacent to the scale are unusual and may suggest the onset of non-protective behavior. While $\mathrm{FeCrAl}$ alloys are $50+$ years old,${ }^{[37,38]}$ few prior studies examined their high-temperature performance in steam or for such short time periods. Thus, these high-temperature steam oxidation conditions are unexplored until now. Previous experimental work were for applications such as heating elements or fossil-fuel power generation heat exchangers where multi-year lifetimes were desired at $\sim 1373 \mathrm{~K}$ $\left(1100{ }^{\circ} \mathrm{C}\right) .{ }^{[39]}$ The ramp testing of model alloys suggests that $\mathrm{Cr}, \mathrm{Al}$, and $\mathrm{Y}$ are all beneficial to maximum operating temperature. ${ }^{[14]}$ However, some anomalies, like that shown in Figure 5 remain, and further study is in progress. Typically, the diffusion rate of $\mathrm{Al}$ is considered rapid and microstructure is not an important factor, but

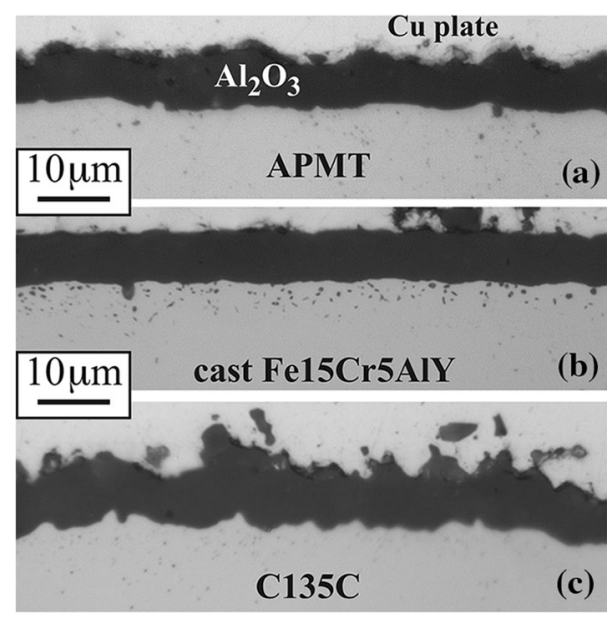

Fig. 8- Light microscopy of polished cross sections of specimens exposed to 1 bar steam at $1673 \mathrm{~K}\left(1400{ }^{\circ} \mathrm{C}\right)(a)$ APMT, $(b) 1$ st generation Fe15Cr5AlY, and (c) 2nd generation C135C.

those assumptions may need to be revisited based on different behaviors of cast and wrought $\mathrm{Fe}-15 \mathrm{Cr}-5 \mathrm{Al}+$ Y, Figures 5 and 8(b).

Finally, while these results for low-Cr FeCrAl alloys are positive, a substantial amount of work remains to fabricate high-quality thin-walled tubing and demonstrate its operational performance in $\sim 593 \mathrm{~K}\left(320^{\circ} \mathrm{C}\right)$ water, e.g., long-term corrosion rates, irradiation resistance, and any synergism between oxidation behavior and radiation (both at high and low temperature).

\section{SUMMARY}

The high-temperature steam oxidation resistance of several alternative cladding materials was investigated for improved accident tolerance. The mass loss of $\mathrm{La}_{2} \mathrm{O}_{3}$-dispersed Mo in steam at $1073 \mathrm{~K}\left(800^{\circ} \mathrm{C}\right)$ was less than in dry air, but sill very rapid. At $1473 \mathrm{~K}\left(1200{ }^{\circ} \mathrm{C}\right), \mathrm{Ti}_{3} \mathrm{SiC}_{2}$ did not form a protective scale and results for $\mathrm{Ti}_{2} \mathrm{AlC}$ suggested that single-phase laboratory material formed a slower growing alumina scale compared to commercial $\mathrm{Ti}_{2} \mathrm{AlC}$. Fabricating $\mathrm{Ti}_{2} \mathrm{AlC}$ coatings will likely be a challenge for fuel cladding applications. For FeCrAl, alloy development is in progress for a $\mathrm{Fe}-13 \mathrm{Cr}-5 \mathrm{Al}$ base composition with improved tensile properties due to optimized composition and heat treatment. For steam oxidation resistance, one key area remaining for $\mathrm{FeCrAl}$ alloy development is to retain the highest temperature capability, similar to the $1748 \mathrm{~K}\left(1475^{\circ} \mathrm{C}\right)$ temperature limit for the commercial FeCrAl alloy APMT.

\section{ACKNOWLEDGMENTS}

The experimental work was conducted by $\mathrm{M}$. Howell, A. Willoughby, M. Stephens, T. Lowe, H. Longmire, and $\mathrm{T}$. Jordan. The high-purity $\mathrm{Ti}_{2} \mathrm{AlC}$ was provided by $\mathrm{M}$. Radovic, Texas A\&M University. K.G. Field and G. Muralidharan provided useful 
comments on the manuscript. This research was funded by the U.S. Department of Energy's Office of Nuclear Energy, Advanced Fuel Campaign of the Fuel Cycle R\&D program.

\section{REFERENCES}

1. R. Gauntt, et al.: Fukushima Daiichi Accident Study (Status as of April 2012), Sandia National Laboratory Report, SAND2012-6173, Albuquerque, NM, 2012.

2. K.R. Robb, M.W. Francis, and L.J. Ott: Nucl. Technol., 2014, vol. 186, pp. 145-60.

3. T. Cheng, J.R. Keiser, M.P. Brady, K.A. Terrani, and B.A. Pint: $J$. Nucl. Mater., 2012, vol. 427, pp. 396-400.

4. B.A. Pint, K.A. Terrani, M.P. Brady, T. Cheng, and J.R. Keiser: $J$. Nucl. Mater., 2013, vol. 440, pp. 420-27.

5. K.A. Terrani, C.M. Parish, D. Shin, and B.A. Pint: J. Nucl. Mater., 2013, vol. 438, pp. 64-71.

6. Y. Yan, J.R. Keiser, K.A. Terrani, G.L. Bell, and L.L. Snead: $J$. Nucl. Mater., 2014, vol. 448, pp. 436-40.

7. K.A. Terrani, S.J. Zinkle, and L.L. Snead: J. Nucl. Mater., 2014, vol. 448 , pp. $420-35$.

8. S.J. Zinkle, K.A. Terrani, J.C. Gehin, L.J. Ott, and L.L. Snead: $J$. Nucl. Mater., 2014, vol. 2014 (448), pp. 374-79.

9. M.T. Farmer, L. Leibowitz, K.A. Terrani, and K.R. Robb: $J$. Nucl. Mater., 2014, vol. 448, pp. 534-40.

10. A.T. Nelson, E.S. Sooby, Y.-J. Kim, B. Cheng, and S.A. Maloy: $J$. Nucl. Mater., 2014, vol. 448, pp. 441-47.

11. J.W. Byeon, J. Liu, M. Hopkins, W. Fischer, N. Garimella, K.B. Park, M.P. Brady, M. Radovic, T. El-Raghy, and Y.H. Sohn: Oxid. Met., 2007, vol. 68, pp. 97-111.

12. S. Basu, N. Obando, A. Gowdy, I. Karaman, and M. Radovic: $J$. Electrochem. Soc., 2012, vol. 159 (2), pp. C90-96.

13. K.A. Terrani, B.A. Pint, C.M. Parish, C.M. Silva, L.L. Snead, and Y. Katoh: J. Am. Ceram. Soc., 2014, vol. 97, pp. 2331-52.

14. B.A. Pint, K.A. Unocic, and K.A. Terrani: Mater. High Temp., 2015, vol. 32, pp. 28-35.

15. B.A. Pint, K.A. Terrani, J.R. Keiser, M.P. Brady, Y.Yamamoto, and L.L. Snead: NACE Paper ED2013-3083, Houston, TX, Presented at the 16th Environmental Degradation conference, Asheville, NC, 2013.

16. J.V. Cathcart, R.E. Pawel, R.A. McKee, R.E. Druschel, G.J. Yurek, and J.J. Campbell et al.: Zirconium metal-water oxidation kinetics, IV: reaction rate studies, ORNL/NUREG-17, Oak Ridge National Laboratory, 1977.

17. H.C. Brassfield, J.F. White, L. Sjodahl, and J.T. Bittel: Recommended Property and Reaction Kinetics Data for Use in Evaluating a Light-Water-Cooled Reactor Loss of Coolant Incident
Involving Zircaloy-4 or 304SS Clad $\mathrm{UO}_{2}$, GEMP-482, General Electric Co., 1968.

18. A. Strasser, J. Santucci, K. Lindquist, W. Yario, G. Stern, L. Goldstein, and L. Joseph: An Evaluation of Stainless Steel Cladding for Use in Current Design LWRs, Report NP-2642, Electric Power Research Institute, Palo Alto, CA, 1982.

19. M.H. Mathon, Y. de Carlan, G. Geoffroy, X. Averty, A. Alamo, and C.H. de Novion: J. Nucl. Mater., 2003, vol. 312, pp. 236-48.

20. G. Bonny, D. Terentyev, and L. Malerba: Scripta Mater., 2008, vol. 59, pp. 1193-96.

21. M. Ben-Belgacem, V. Richet, K.A. Terrani, Y. Katoh, and L.L. Snead: J. Nucl. Mater., 2014, vol. 447, pp. 125-42.

22. Y. Katoh, K.A. Terrani, and L.L. Snead: Systematic Technology Evaluation Program for $\mathrm{SiC} / \mathrm{SiC}$ Composite-based Accident-Tolerant LWR Fuel Cladding and Core Structures, ORNL/TM-2014/ 210, Oak Ridge, TN, 2014.

23. I.G. Wright and R.B. Dooley: Mater. High Temp., 2011, vol. 28, pp. $40-57$.

24. E.A. Gulbransen, K.F. Andrew, and F.A. Brassart: J. Electrochem. Soc., 1963, vol. 110, pp. 952-59.

25. M. Kilpatrick and S.K. Lott: J. Phys. Chem., 1965, vol. 69, pp. $1638-40$

26. G.R. Belton and A.S. Jordan: J. Phys. Chem., 1965, vol. 69, pp. 2065-71.

27. M.W. Barsoum: Prog. Solid State Chem., 2000, vol. 28, pp. 20181.

28. P. Eklund, M. Beckers, U. Jansson, H. Högberg, and L. Hultman: Thin Solid Films, 2010, vol. 518, pp. 1851-78.

29. G.M. Song, V. Schnabel, C. Kwakernaak, S. Van der Zwaag, J.M. Schneider, and W.G. Sloof: Mater. High Temp., 2012, vol. 29, pp. 205-09.

30. H.B. Zhang, Y.W. Bao, and Y.C. Zhou: J. Mater. Sci. Technol., 2009, vol. 25, pp. 1-38.

31. J.P. Mazzoccoli, E.J. Lahoda and P. Xu: US Patent App. 13/ 670,808, 2012.

32. K.G. Field, X. Hu, K. Littrell, Y. Yamamoto, and L.L. Snead: $J$. Nucl. Mater., 2015, vol. 465, pp. 746-55.

33. F.H. Stott, G.C. Wood, and J. Stringer: Oxid. Met., 1995, vol. 44, pp. 113-45.

34. Y. Yamamoto, B.A. Pint, K.A. Terrani, K.G. Field, Y. Yang, and L.L. Snead: J. Nucl. Mater., in press.

35. B.A. Pint, S. Dryepondt, K.A. Unocic, and D.T. Hoelzer: JOM, 2014, vol. 66, pp. 2458-66.

36. K.A. Unocic, D.T. Hoelzer, and B.A. Pint: Mater. High Temp., 2015, vol. 32, pp. 123-32.

37. E.A. Gulbransen and K.F. Andrew: J. Electrochemical Society, 1959, vol. 106, pp. 294-302.

38. C.S. Wukusick and J.F. Collins: Materials Research Standard, 1964, vol. 4, pp. 637-46.

39. B.A. Pint, S. Dryepondt, A. Rouaix-Vande Put, and Y. Zhang: JOM, 2012, vol. 64, pp. 1454-60. 